\title{
Erratum to: Progress in integrative systems biology, physiology and medicine: towards a scale-relative biology
}

\author{
Charles Auffray ${ }^{1, \mathrm{a}}$, Denis Noble ${ }^{2, \mathrm{~b}}$, Laurent Nottale ${ }^{3, \mathrm{c}}$, Philip Turner ${ }^{4, \mathrm{~d}}$ \\ ${ }^{1}$ European Institute for Systems Biology and Medicine (EISBM), 7 Parc des Cèdres, Vourles, France \\ 2 Department of Physiology, Anatomy and Genetics, Balliol College, Oxford University, Parks Road, Oxford OX1 3PT, UK \\ ${ }^{3}$ LUTH, Observatoire de Paris-Meudon, 5 Place Janssen, 92190 Meudon, France \\ ${ }^{4} 69$ Hercules Road, Devon PL9 8FA, UK
}

Published online: 17 June 2020

(C) The Author(s) 2020

\section{Erratum to:}

Eur. Phys. J. A (2020) 56:88

https://doi.org/10.1140/epja/s10050-020-00090-3

The original version of this article was revised due to a retrospective Open Access order.

The article "Progress in integrative systems biology, physiology and medicine: towards a scale-relative biology", written by Charles Auffray, Denis Noble, Laurent Nottale, Philip Turner, was originally published electronically on the publisher's internet portal on March 182020 without open access.With the author(s)' decision to opt for Open Choice the copyright of the article changed on May 192020 to () The Author(s) 2020 and the article is forthwith distributed under a Creative Commons Attribution 4.0 International License (https://creativecommons.org/licenses/by/4.0/), which permits use, sharing, adaptation, distribution and reproduction in any medium or format, as long as you give appropriate credit to the original author(s) and the source, provide a link to the Creative Commons licence, and indicate if changes were made.
Open Access This article is licensed under a Creative Commons Attribution 4.0 International License (https:// creativecommons.org/licenses/by/4.0/), which permits use, sharing, adaptation, distribution and reproduction in any medium or format, as long as you give appropriate credit to the original author(s) and the source, provide a link to the Creative Commons licence, and indicate if changes were made.The images or other third party material in this article are included in the article's Creative Commons licence, unless indicated otherwise in a credit line to the material. If material is not included in the article's Creative Commons licence and your intended use is not permitted by statutory regulation or exceeds the permitted use, you will need to obtain permission directly from the copyright holder. To view a copy of this licence, visit http://creativecommons.org/ licenses/by/4.0/.

Open Access This article is licensed under a Creative Commons Attribution 4.0 International License, which permits use, sharing, adaptation, distribution and reproduction in any medium or format, as long as you give appropriate credit to the original author(s) and the source, provide a link to the Creative Commons licence, and indicate if changes were made. The images or other third party material in this article are included in the article's Creative Commons licence, unless indicated otherwise in a credit line to the material. If material is not included in the article's Creative Commons licence and your intended use is not permitted by statutory regulation or exceeds the permitted use, you will need to obtain permission directly from the copyright holder. To view a copy of this licence, visit http://creativecomm ons.org/licenses/by/4.0/.

The original article can be found online at https://doi.org/10.1140/ epja/s10050-020-00090-3.

\footnotetext{
a e-mail: cauffray@eisbm.org (corresponding author)

be-mail: denis.noble@dpag.ox.ac.uk

c e-mail: laurent.nottale@obspm.fr

de-mail: pturner.physics@outlook.com
} 